\title{
Cloud Computing as a Prospect for the Sector of Small - and Medium-Size Companies in the Polish Market
}

\author{
Marlena Krakowiak, Teresa Bajor \\ Czestochowa University of Technology, Poland
}

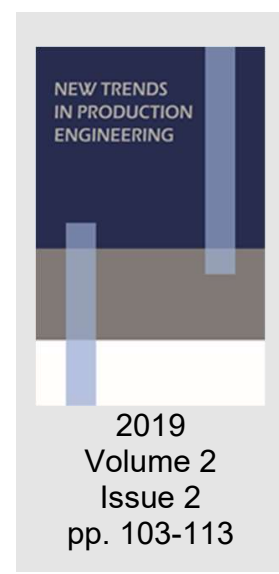

Date of submission to the Editor: 09/2019

Date of acceptance by the Editor: 11/2019

\section{INTRODUCTION}

Changes occurring in the goods and services market require entrepreneurs to have the ability to adjust to their customers' expectations, to rival their competitors and, above all, to undertake innovative activities. The use of modern IT technologies enable the entrepreneurs to attain an increasingly high level of development in this area and to implement modifications, in a broad sense, almost immediately. One of the main objectives of entrepreneurs is to take care of their customers and to win new selling markets for manufactured goods and provided services, which quite often requires high expenditures on marketing purposes. Globalization is an opportunity for the sector of large companies, but also for those ranked among small and medium-sized enterprises, and an unquestionable tool useful for this purpose is the Cloud Computing technology. It comprises a set of services and products which can be taken advantage of, regardless of the user's place and time, and above all, without being dependent on the software installed on the user's computer or other mobile device, as the operational data is processed and recorded through cloud computing (Grance and Mell, 2011). Using offered solutions is convenient and does not require incurring financial expenditures on building a new or expanding the existing IT infrastructure, its maintenance and specialized servicing (Huth \& Cebula, 2011). The cloud provides entrepreneurs the capability to apply its functionalities in various areas of their business activity (such as production, accountancy, sales, purchases, CRM, inventory management, etc.). The solution offers numerous possibilities of sending information between cooperating entities. Figure 1 shows a schematic diagram of information flow between cooperating parties via cloud computing technology.

Different areas of business activity, as seen from the point of view of their management, have different requirements for structure and functionality. Using cloud computing solutions provides enterprises a potential for greater flexibility in a chosen area by using modern, efficient and proven tools with technical support provided by the cloud owner. 


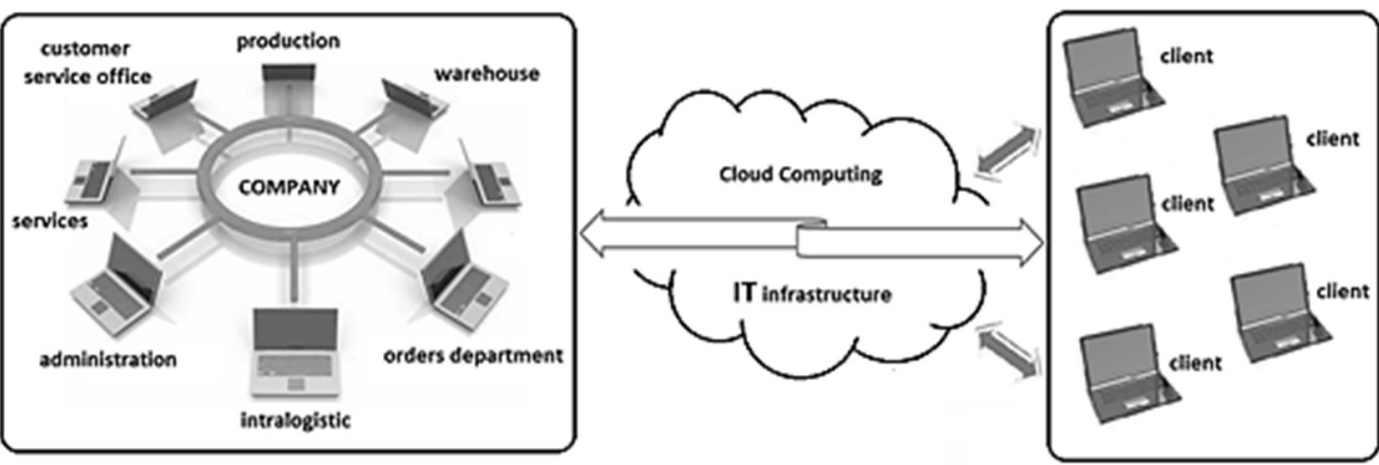

Fig. 1 Schematic diagram of the flow of information between cooperating Source: The author's study parties using cloud computing

If we quote the data for the Polish entrepreneurs of the large and small-size enterprise sector (Wyskwarski, 2014), we will find that, as of today, they are still reluctant to avail themselves of the cloud offer - approx. $11 \%$ of companies (Rosmanowska, 2019), in contrast to private users (natural persons). This situation can be explained by the fear of the process of adapting the public cloud in their organization in a manner that is safe and adjusted to their specific business needs. The fear of loosing sensitive data or having it intercepted by unauthorized persons has much higher priority than the cost of maintaining an internal IT infrastructure. Quite often, this involves changing the current philosophy of conducting business activity and becoming dependent on the acts of the company offering access to IT infrastructure in the cloud. Figure 2 shows potential causes of the dilemma of a Polish entrepreneur over undertaking business activity using cloud computing technology.

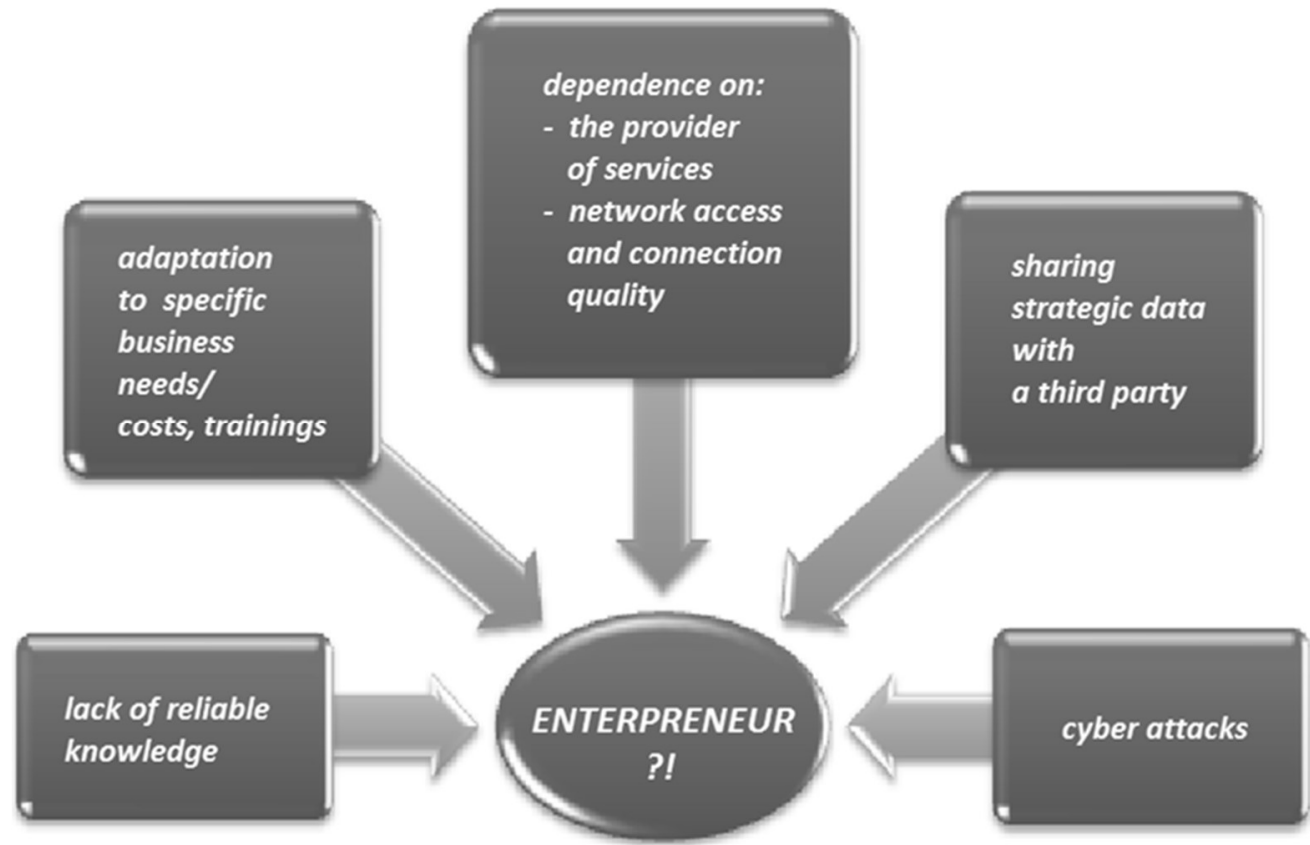

Fig. 2 The fear of an entrepreneur of joining cloud computing Source: The author's study

Cloud computing service platforms that offer safe computing power, and which are most commonly used by Polish entrepreneurs include: Amazon Web 
Services, Microsoft Azure, Oktawave, e24cloud, Netia Compute, Google Cloud Platform, IBM Bluemix, Oracle Cloud, Integrated Solutions - Integrated Computing (Chmurowisko, 2019). For example, the range of capabilities offered by Amazon Web Services comprises currently approx. 110 different services. The most widely known of them include a service that provides scalable cloud computing power and data storage in the cloud in the form of single files of a size ranging from 1 byte to 5 terabytes, in so-called buckets.

\section{A POLISH COMPUTING CLOUD AND INDUSTRY 4.0 CONCEPT}

Due to dynamic changes in the IT solutions market, an offer has also come up in the Polish market, which is created by institutions with State capital and is addressed to domestic entrepreneurs. In October last year, the Polish Development Fund and the PKO BP bank announced the establishment of a company with the aim of creating a national computing cloud, which is an unquestionable opportunity to Polish enterprises. This means to be a technological infrastructure that will offer remote data processing, maintaining services and rendering services (Tarkowski, 2018). Acting as a technological and legal platform, the Polish cloud will stimulate the growth of innovations in domestic enterprises, while enabling the establishment of a modern public administration.

The first stage of activities is to put forward an offer for laaS and PaaS services (Bajor, Krakowiak, 2012) for strategic customers. At the second stage, on the other hand, pilot services will be made available to a wider group of customers. The full availability of the offer for target users is planned in 2020 (Portal Gospodarczy, 2019). The above-mentioned initiative fits into the Government strategy of nationwide digitalization. An impulse to its undertaking was the sovereignty of the Internet and exercising control over sensitive data and key services on the territory of the Polish State. An example of the Polish State's activity in this field is the already established Government computation cloud operating based on IT resources possessed by the Ministry of Digitalization. These resources are managed by the Central Information Technology Centre. The solution referred to above is a safe solution dedicated to systems that are essential from the State's point of view, including the State's records. Presently, two systems are located in the cloud, namely: mObywatel and Otwarte Dane (Ministerstwo cyfryzacji, 2019). Therefore, the location of severs seems to be crucial, because it determines what laws will regulate the operation of services and the circulation of data in the cloud, which has a geopolitical dimension. The governments of many countries, taught by experiences - Edward Snowden's case (Edwardsnowden Official Website, 2019), try not to store their data abroad. There is the view that a threat to the sovereignty of data stored and processed in data clouds can be the domination of large American technological concerns in the sector of this activity. The market situation should, therefore, be regulated, and one of such regulation mechanism may be building alternative, antitrust solutions. 
The objective of the launched Polish computing cloud project is to offer sovereign public services (the servers are to be located on the territory of Poland and remained under the control of national State-owned companies and public administration). Thus, financial resources currently located in foreign capital ventures will remain at home. This is a step towards the vision of a technologically sovereign country being prepared for the 4th technological revolution.

In the area of Industry 4.0, the company's production system will consist of an information system and numerically controlled machines that will operate autonomously and exhibit elements of artificial intelligence. This concept should be considered individually, depending on the needs and size of the enterprise (Wittbrodt \& Łapuńka, 2017).

The main elements that are closely related to the idea of Industry 4.0 include: industrial internet of things (IloT), cloud-based manufacturing (CBM), smart factories (SF), cyber-physical systems (CPS) or social product development (SPD) (Hermann et al., 2015).

The idea of IloT is to collect large amounts of data from production processes and send them to processing canters. Industrial Control Systems (ICS) can also be included in the industrial internet of things, which use advanced communication technologies based on the Internet so allows for fast integration with the company's IT systems.

An important component of the cloud computing is the so-called Cloud-based Manufacturing (CBM). It is a network model of the production system that creates temporary, reconfigurable, cyber-physical manufacturing lines from diversified and dispersed production resources. The use of network models allows the allocation of production resources in response to customer demand, which contributes to increased productivity and reduces cost of the product life cycle.

The Smart Factory concept provides integration at all levels of production resources, thus ensuring a high level of flexibility and adaptation to continuous changes in the market.

The Cyber-Physical Systems (CPS) are a combination of the computational layer and physical processes. Integration usually occurs in the form of embedded systems and networks for monitoring and controlling physical processes.

The Social Product Development (SPD) is a relatively new concept in the world of product development, therefore, is typically not clearly defined. It is assumed that this is the involvement of a qualified group of people inside or outside the company in product development. Technologies, social tools and media are used to this purpose, thanks to which users can have an impact on the product life cycle at every stage of its design. Such a new product launched on the market, has a shorter development time and needs less investment than in similar projects based solely on traditional design (Peterson \& Schaefer, 2014). The idea of the fourth industrial revolution - Industry 4.0 concept (Rojko, 2017) promotes the levelling of the implementation of intelligent technologies in 
enterprises regardless of their branch and size. It involves universal digitization, ensuring constant communication between people and devices, increasing the implemented Disruptive Innovations (Clayton et al., 2015) allowing for a rapid increase in the efficiency of the socio-economic system and the development of autonomously functioning machines through the use of artificial intelligence. The latest report by the Ministry of Enterprise and Technology and Siemens 'Smart Industry Polska 2018', which researches innovation in the micro and small manufacturing sector, shows that the idea of Industry 4.0 is of real significance among Polish enterprises (Batorska, 2018).

The structure of the enterprise market in Poland presented in Figure 3 shows a high share of the SME sector.

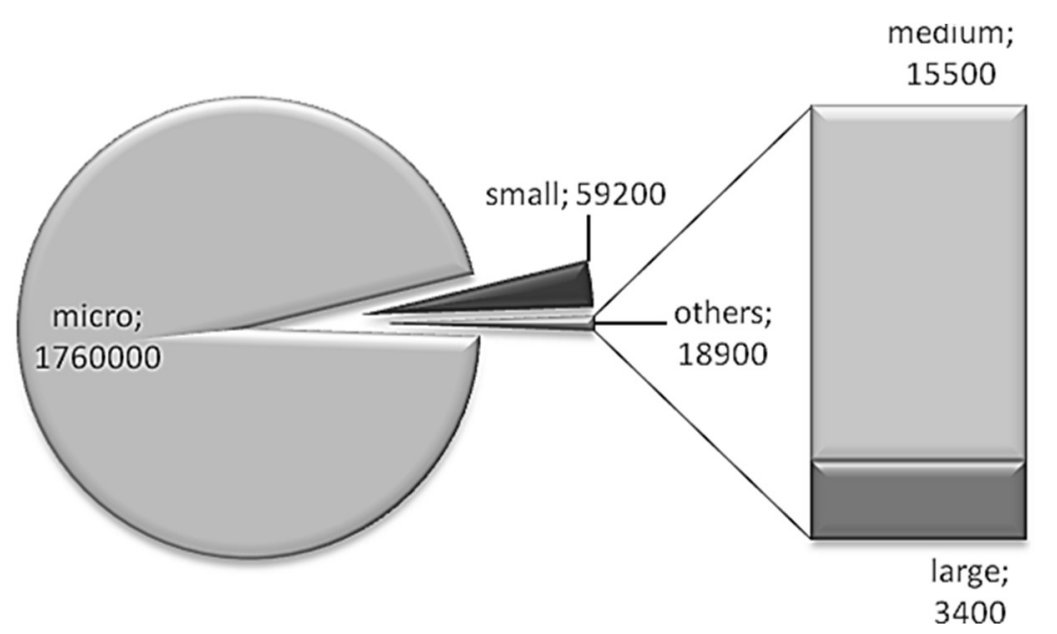

Fig. 3 List of the number of enterprises in Poland by their size (in thousands) Source: The author's study based on (Kulik et. al., 2018)

This sector, dynamically developing over the last years, has a significant share in generating GDP and creating the labor market (Figure 4).

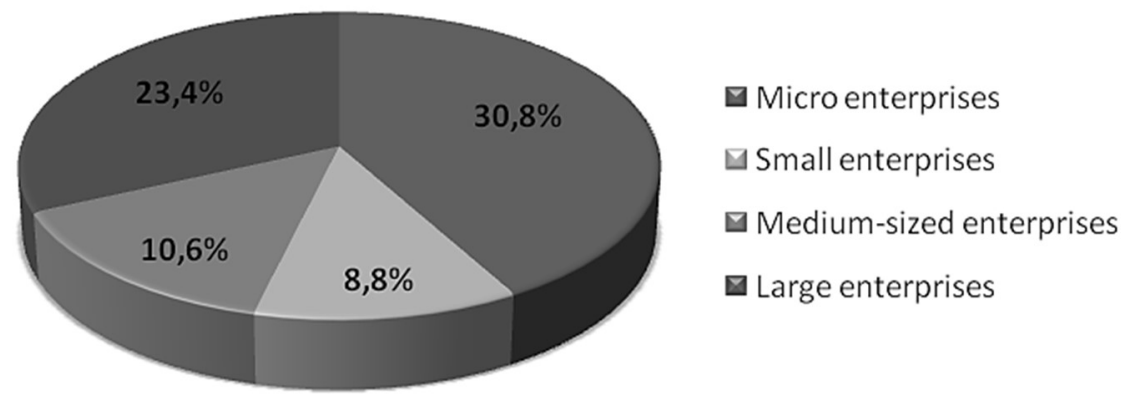

Fig. 4 Percentage share in GDP creation by individual groups of enterprises in Poland in 2016 Source: The author's study based on (Kulik et. al., 2018)

Enterprises that implement innovative technological solutions count primarily on reducing production costs and obtaining a competitive advantage. The technologies with the greatest impact on the company's profits growth include: automation of production lines, data analytics and software that reduce the costs of prototyping and introducing new products as shown in Figure 5. 


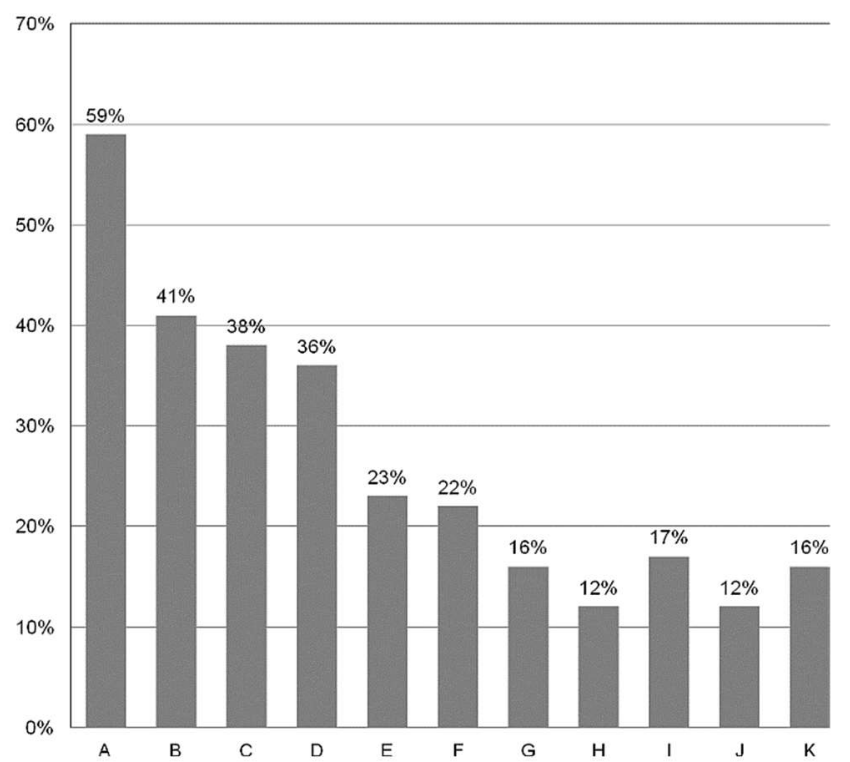

Fig. 5 Technologies and solutions supporting company innovativeness (percentage level of application according to responders):

A - automation of production lines, B - data analytics, C - robotization of production lines, D - software that reduces the cost of prototyping and the introduction of new products,

E - collaborative robots, $F$ - 3D printing, $G$ - industrial internet of things,

$\mathbf{H}$ - internet of things, I - Big Data, $\mathbf{J}$ - cloud computing, $\mathrm{K}$ - artificial intelligence

Source: The author's study based on (Batorska, 2018)

\section{INNOVATION AND CLOUD COMPUTING}

Cloud computing solutions are gaining a key position in the development of technological innovations. The aspiration of entrepreneurs to achieve success in an aggressively competing market makes the interest in such tools constantly grow. The leaders in the European market are Scandinavian countries, such as: Finland, Sweden and Denmark, which use cloud solutions in nearly $70 \%$.

GUS (Central Statistical Office) data on investments by domestic companies into new technologies proves the interest of Polish entrepreneurs in the application of new solutions. Figure 6 shows the average share of innovative enterprises in the overall number of domestic enterprises.

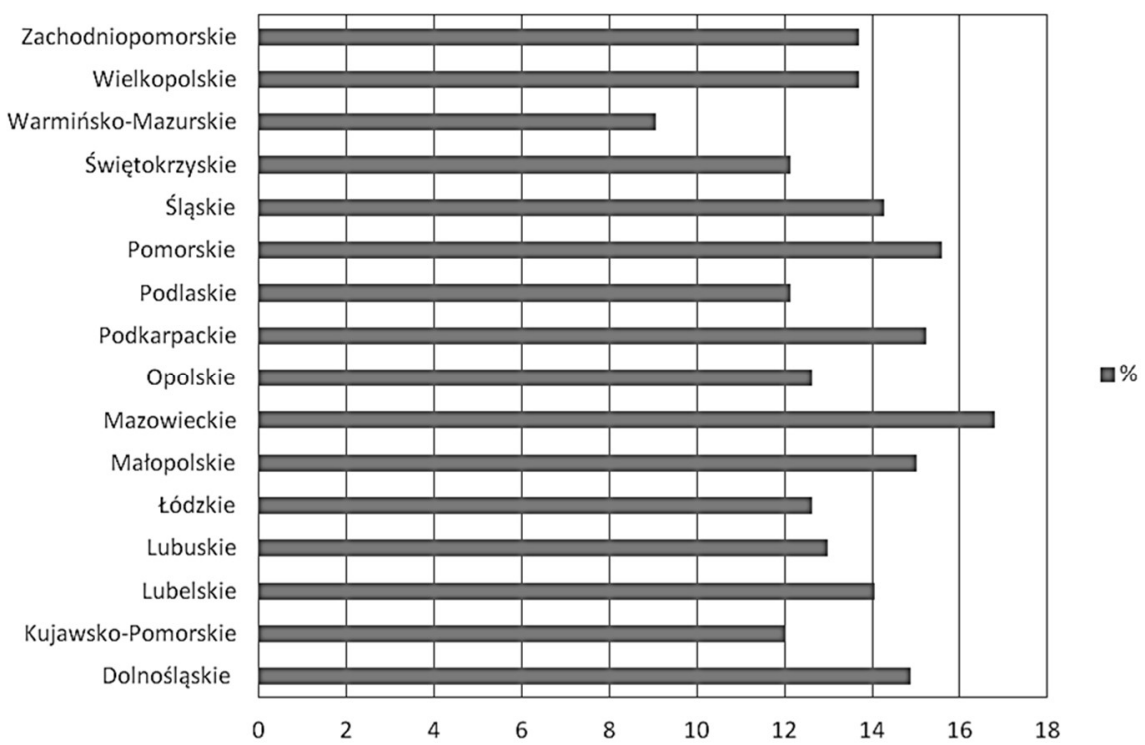

Fig. 6 The average share of innovative enterprises in the overall number of enterprises in 2017 Source: The author's compilation based on (GUS data, 2019). 
A leader in this respect is the Mazowieckie District. While Figure 7 presents the volume of expenditures on innovative solutions, depending on the types of business activity. When analyzing the diagram, significant differences in the sum of invested financial resources can be noticed between individual areas.

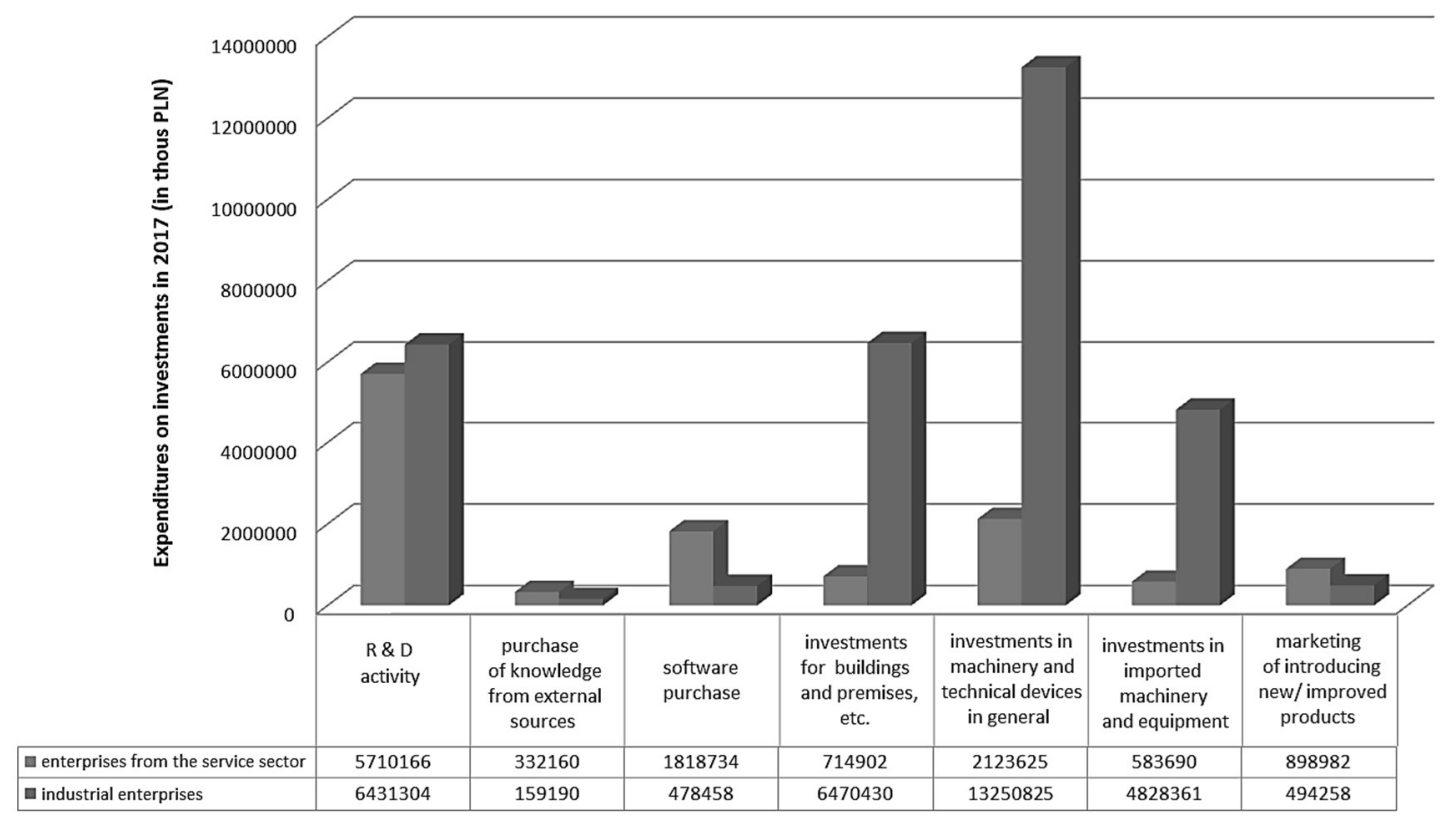

Fig. 7 Expenditures on innovation activity in enterprises by the types of innovation activity in $\mathbf{2 0 1 7}$

Source: The author's compilation based on (GUS data, 2019)

The relatively low share of investment expenditures on the purchase of knowledge from external sources and the purchase of software may suggest a still low confidence in modern IT tools, such as cloud computing, which is closely related with the possibility of allocating enterprises' financial resources.

\section{CLOUD SAFETY}

One of the fundamental dilemmas that entrepreneurs contend with prior to proceeding with collaboration with platforms offering cloud services is the issue of stored data safety. The philosophy of functioning of those solutions relies on using software and IT infrastructure at the external supplier, often even at a geographically Data Center (Magazyn Computerworld, 2019).

According to the Chief Personal Data Protection Inspectorate (Główny Inspektorat Ochrony Danych Osobowych, GIODO) the processing of data in a cloud is legally acceptable. In the case of storing classified information, the problem arises with meeting the contractual conditions for the storage of data on external servers. It is worth being aware of the cost of the inadequate protection of sensitive data. For transmitting such information in an illegal manner the entrepreneur may pay a fine ranging from 50 thousand to 200 thousand zlotys. For those guilty of negligence in this respect, a prison sentence to two years is also possible (Magazyn Computerworld, 2019).

Relevant laws and regulations applicable to data protection and confidentiality clauses are only one of the user safety protection aspects. Exposure to 
cyberterrorism and unauthorized access to computing cloud resources using advanced IT knowledge, including the darknet, creates the need for the diversification of cloud owners' activities, as shown in Figure 8.

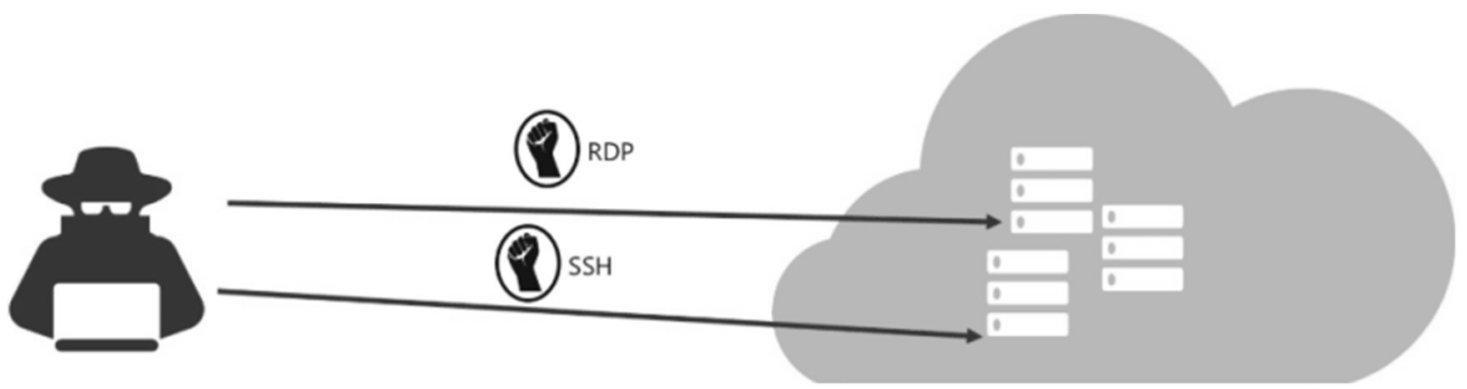

Fig. 8 Schematic diagram illustrating the methods of intercepting cloud data Source: (Chmurowisko, 2019)

In many instances it is necessary to use system and procedural solutions that may reduce the risk of data leak (Chmurowisko, 2019), which is in the area of responsibility of the company providing cloud computing services, as it is the guarantor of the safe use of the solution in question. Failure to comply with obligations will result in a loss of reputation and reliability by the company providing the service.

Well thought-out decisions for the selection of services available in the market and control encompassing: monitoring, encoding, filtrating and blocking sensitive information contained in rest data, data in motion and data in use, are among the most important elements of the general data protection strategy (Bajor, Dobrakowski, 2015).

\section{ADVANTAGES AND DRAWBACKS OF CLOUD COMPUTING}

The technology offered within cloud computing has numerous advantages and meets the requirements of contemporary world markets by enabling the development and application of innovative solutions for SME sector companies who, quite often, are unable by themselves to face financial requirements involved with the marketing of innovations. While standing in admiration of the wide range of capabilities and applications of the state-of-art IT solutions, it is impossible to pass over threats that arise in connection with this type of activity (Krakowiak, Bajor, 2018). Table 1 summarizes potential threats and advantages involved with the use of cloud computing services.

Table 1 A summary of advantages and disadvantages (potential threats) of offered cloud solutions

\begin{tabular}{|c|c|}
\hline \multicolumn{2}{|c|}{ Cloud computing } \\
\hline Advantages: & Disadvantages/potential threats: \\
\hline $\begin{array}{l}\text { remote access (network connection), } \\
\text { mobility; }\end{array}$ & $\begin{array}{l}\text { connection interception; } \\
\text { no Internet access; } \\
\text { crash, system failure; }\end{array}$ \\
\hline $\begin{array}{l}\text { safety of stored } \\
\text { and processed data; }\end{array}$ & $\begin{array}{l}\text { leak of sensitive, strategic data; } \\
\text { dulling the user's vigilance; }\end{array}$ \\
\hline $\begin{array}{l}\text { firewall, the system of multilevel } \\
\text { protection against unauthorized access; }\end{array}$ & $\begin{array}{l}\text { cyber attacks; } \\
\text { data takeover; } \\
\text { information trading; }\end{array}$ \\
\hline
\end{tabular}




\begin{tabular}{|l|l|}
\hline $\begin{array}{l}\text { up-to-date software; } \\
\text { modern applications } \\
\text { and systems; }\end{array}$ & $\begin{array}{l}\text { deficiencies in operation skills and the } \\
\text { associated need for supplementary training; } \\
\text { likely operation faults; }\end{array}$ \\
\hline technical and training support; & $\begin{array}{l}\text { dependence on the service provider; } \\
\text { making strategic and sensitive data available } \\
\text { to third parties; } \\
\text { difficult changing services from one platform } \\
\text { to another; }\end{array}$ \\
\hline reduced operation costs; & $\begin{array}{l}\text { confidence in the IT service provider; } \\
\text { dependence; } \\
\text { high costs of services provided; }\end{array}$ \\
\hline access to various analyses; & $\begin{array}{l}\text { data sharing; } \\
\text { access to the knowledge of the company's } \\
\text { business activity weaknesses; }\end{array}$ \\
\hline reliability, failure-free operation; & $\begin{array}{l}\text { dependence on the provided IT infrastructure } \\
\text { and technical support; }\end{array}$ \\
\hline $\begin{array}{l}\text { versatility and flexibility } \\
\text { of provided solutions; }\end{array}$ & $\begin{array}{l}\text { confidence in software adaptation specialists; } \\
\text { unfamiliarity with, and lack of the solid } \\
\text { knowledge of the solutions used; }\end{array}$ \\
\hline $\begin{array}{l}\text { private cloud, e.g. for the administration } \\
\text { of State institutions; }\end{array}$ & $\begin{array}{l}\text { taking control, e.g. over State administration, } \\
\text { and access to strategic data; }\end{array}$ \\
\hline innovativeness; & dependence on the provided IT infrastructure; \\
\hline sharing the IT infrastructure; & $\begin{array}{l}\text { failures; } \\
\text { hostile takeover; } \\
\text { dependence; }\end{array}$ \\
\hline globalization; & new threats on a global level; \\
\hline $\begin{array}{l}\text { using the services } \\
\text { of global technological concerns; }\end{array}$ & exposure to data control by hostile powers. \\
\hline
\end{tabular}

Source: The author's study

\section{SUMMARY}

The idea behind the Internet was its trans-national character, freedom of transmitted contents, no censorship and public exchange of information. Nowadays, however, because of the globalization and technological progress, views about the Internet sovereignty are becoming prominent (e.g. the Chinese model). The introduction of numerous mobile solutions, such as mobile payment systems, the digitalization of financial services, purchasing platforms, internet services and social networking sites, all drive the need for a market based on technological innovations, and especially cyber technologies. This is a bold step into the future, which moves us away from traditional solutions, paper documents, personal contacts, being limited to local markets.

The well thought-out and planed induction of an enterprise (especially a SME) into modern market solutions using cloud computing technology, while being aware of their unquestionable advantages, but also potential threats, will enable any entrepreneur who is inclined to build a long-lasting strategy for achieving success, to prepare themselves for entering the realities of the so-called 4th industrial revolution. It is therefore essential to make an analysis of the enterprise, set the goals and secure resources for achieving them, while taking into account the risk associated with a possible loss of data and contemporary challenges. The cloud computing technology should be oriented to the dynamic of changes in the contemporary market. A good solution is to choose reputed technological platforms that enjoy the confidence of their customers. The Polish computing cloud will certainly find its supporters among domestic entrepreneurs, 
at least for patriotic reasons, but also because of the independence and safety of stored and processed data, which it is expected to ensure. With the appropriate support on the Government part, it will help to break the existing resistance and increase the share of Polish enterprises in the world's market of innovations and cyber technologies.

Using services in the cloud will allow small and medium enterprises to reduce operating costs, increase the technical level in the area of IT solutions and increase flexibility in making investment decisions.

\section{REFERENCES}

Bajor T., Dobrakowski (2015). Bezpieczeństwo przechowywania danych wrażliwych w rozwiązaniach Cloud Computing, Logistyka, nr 6, 2015, pp. 9-13

Bajor T., Krakowiak M. (2012). Cloud computing a rynek usług, Logistyka nr 6, pp. 1921

Batorska S. (2018). Smart Industry Polska 2018. Raport o innowacyjności MŚP, [online] Available at: https://automatykaonline.pl/Artykuly/Przemysl-4.0/Smart-IndustryPolska-2018.-Raport-o-innowacyjnosci-MSP [Accessed 15.05.2019]

Chmurowisko.pl (2019) Chmurowisko Official Website. [online] Available at: https://chmurowisko.pl/ [Accessed 19.03.2019]

Clayton M. Christensen, Michael E. Raynor, Rory McDonald (2015). What Is Disruptive Innovation? In: Harvard Business Review, Available at: https://hbr.org/2015/12/what-is-disruptive-innovation [Accessed 20.05.2019]

Edwardsnowden.com (2019) Edwardsnowden Official Website [online], Available at: https://edwardsnowden.com/ [Accessed 20.03.2019]

Główny Urząd Statystyczny, (2018). stat.gov.pl [online], Available at: https://stat.gov.pl/obszary-tematyczne/nauka-i-technika-spoleczenstwoinformacyjne/nauka-i-technika/dzialalnosc-innowacyjna-przedsiebiorstw-w-latach2015-2017,2,16.html [Accessed: 29.03.2019]

Grance T., Mell P. (2011). The NIST Definition of Cloud Computing. National Institute of Standards and Technology U.S. Department of Commerce. Special Publication $800 \quad-\quad 145, \quad$ Available at: http://nvlpubs.nist.gov/nistpubs/Legacy/SP/nistspecialpublication800-145.pdf [Accessed 10.05.2019]

GUS data, (2019) [online] Available at: https://bdl.stat.gov.pl/BDL/metadane/podgrupy/432 [Accessed 29.03.2019].

Hermann M., Pentek T., Otto B. (2015). Design Principles for Industrie 4.0 Scenarios: A Literature Review, Technische Universität Dortmund, No. 01

Krakowiak M., Bajor T. (2018). Contemporary Threats Related to the Use of the Network, In: Prace Naukowe Akademii im. Jana Długosza w Częstochowie. Technika, Informatyka, Inżynieria Bezpieczeństwa, T6, pp. 575-590 Available at: http://www.pneti.ajd.czest.pl/docs/tom13/zeszyt_13.pdf [Accessed 10.05.2019]

Kulik M., Krakowiak M., Kawałek A. (2018). OSH in micro and small enterprises of the region, In: Wybrane aspekty bezpieczeństwa funkcjonowania współczesnych organizacji, red. M. Krakowiak, T. Bajor, Wydawnictwo Wydziału Inżynierii Produkcji i Technologii Materiałów Politechniki Częstochowskiej, seria Monografie nr 81, pp. 4-22

Magazyn Computerworld, (2019). www.computerworld.pl [online] [Accessed 18.03.2019]

Ministerstwo cyfryzacji (2019) Polish government service [online] Available at: https://www.gov.pl/web/cyfryzacja/ [Accessed 10.05.2019]

Portal Gospodarczy (2019). wnp.pl, [online]. Available at: https://finanse.wnp.pl/pko-bpi-polski-fundusz-rozwoju-stworza-krajowa-chmureobliczeniowa,333415_1_0_0.html [Accessed: 18.04.2019] 
Peterson A., Schaefer D. (2014). Social Product Development: Introduction, Overview, and Current Status, In: D. Schaefer (ed.), Product Development in the Sociosphere DOI: 10.1007/978-3-319-07404-7_1, Springer International Publishing Switzerland, pp. 1-33 [online] Available at: https://www.researchgate.net/publication/263276452_Social_Product_Developm ent_Introduction_Overview_and_Current_Status [Accessed 19.05.2019].

Rojko A. (2017), Indūstry 4.0 Concept: Background and Overview, iJIM - Vol. 11, No. 5, Available at: https://online-journals.org/index.php/ijim/article/viewFile/7072/4532 [Accessed 19.05.2019]

Rosmanowska M., (2019) „Biznes w chmurze” [online]. Available at: https://www.money.pl/gospodarka/biznes-w-chmurze-nad-rozwiazaniem-dlamilionow-firm-pracuje-rzad-i-najwiekszy-bank-6339898471270017a.html [Accessed 18.03.2019]

Tarkowski A. (2018), Polityka. Ludzie i styl [online]. Available at: https://www.polityka.pl/tygodnikpolityka/ludzieistyle/1770726,1,polska-chmurakrajowa-o-co-chodzi-w-tym-projekcie.read [Accessed: 18.03.2019]

[Accessed 19.03.2019]

Wittbrodt P., Łapuńka I., Przemysł 4.0 - wyzwanie dla współczesnych przedsiębiorstw produkcyjnych, Innowacje w Zarządzaniu i Inżynierii Produkcji, tom II, pod red. R. Knosala, Oficyna Wydawnicza PTZP, Opole 2017, pp.793-799, Available at: http://www.ptzp.org.pl/files/konferencje/kzz/artyk_pdf_2017/T2/t2_793.pdf [Accessed 12.05.2019]

Wyskwarski M. (2014). Cloud computing in order to small enterprises' point of view), Zeszyty naukowe Politechniki Śląskiej, Seria: Organizacja i zarządzanie z. 74, Nr kol. 1921, pp. 641-652

\begin{abstract}
.
Efficient functioning in the contemporary market is a fundamental need of every organization. In times of globalization and an intensive technological and engineering progress, attaining a proper position and retaining it is a big challenge in almost every branch of industry. This is especially difficult for the SME sector, as it requires financial expenditures on system solutions and the IT base, among other things. This is where "Cloud Computing" comes in. Cloud computing services consist in providing and making available IT resources (efficient, scalable and tailored to the customer's needs) through the Web. Thanks to wide access to intensively developing mobile systems, the low costs of computer components and the associated increasingly common use of Internet of Things (IOT) in numerous devices connected to the Internet, data processing is being gradually moved onto the Web peripheries. The purpose of the study is to highlight advantages and possible threats associated with the use of Cloud Computing-based solutions for aiding the activity of enterprises at a varying organizational level following the 4 th industrial revolution.
\end{abstract}

Keywords: cloud computing, globalization, threats, SMEs, Industry 4.0 